\title{
Relative abundance of Archaea and Bacteria along a thermal gradient of a shallow-water hydrothermal vent quantified by rRNA slot-blot hybridization
}

\author{
Stefan M. Sievert, ${ }^{1}$ Wiebke Ziebis, ${ }^{2}$ Jan Kuever ${ }^{1}$ and Kerstin Sahm ${ }^{3} \dagger$
}

Author for correspondence: Stefan M. Sievert. Tel: +49 421 2028738. Fax: +49 4212028580. e-mail: ssievert@mpi-bremen.de

\section{1,2\&3 Departments of Microbiology ${ }^{1}$ and Biogeochemistry2, and Molecular Ecology Group ${ }^{3}$, Max-Planck- Institute for Marine Microbiology, Celsiusstr. 1, D-28359 Bremen, Germany}

\begin{abstract}
Slot-blot hybridization of rRNA with domain-specific oligonucleotide probes targeting the 16S rRNA of Archaea and Bacteria was utilized to assess the relative abundance of these domains along a thermal gradient at a shallow submarine hydrothermal vent near Milos Island (Greece). The highest prokaryotic rRNA concentrations (defined as the sum of bacterial and archaeal rRNA) were found in the uppermost sediment surface $(0-20 \mathrm{~mm})$, decreasing strongly with depth. This indicates that the microbial activity was mainly occurring in the surface layer of this hydrothermal vent. Furthermore, rRNA concentrations were higher in regions closer to the vent, suggesting that the hydrothermal activity stimulated microbial activity. Archaea seemed to be a minor component of the microbial community at this vent site, even in the zones with higher temperatures. Bacteria made up at least $78 \%$ (mean $95 \%$ ) of the prokaryotic rRNA. However, along the steepest temperature gradient, the proportion of archaeal rRNA increased. Nevertheless, even in the hottest sediment layer where a quantification was possible (in situ temperature $82{ }^{\circ} \mathrm{C}$ ) archaeal rRNA made up only $\mathbf{1 1 . 9} \%$ of the prokaryotic rRNA. This suggests that Archaea were generally of minor importance at this vent site and were probably restricted to a narrow niche. The factors that allow Bacteria to dominate in a high temperature environment that was once believed to be the realm of Archaea remain elusive.
\end{abstract}

Keywords: rRNA slot-blot hybridization, Archaea and Bacteria, microbial activity, hydrothermal vent, Milos Island (Aegean Sea, Greece)

\section{INTRODUCTION}

The composition of microbial communities of high temperature hydrothermal vents was, until recently, mainly studied by cultivation-based techniques. Because of the frequent isolation of Archaea from these habitats it was assumed that Archaea dominate these communities (Stetter et al., 1990; Baross \& Deming, 1995). The first cultivation-independent support for that hypothesis came from the analysis of lipids extracted from sulfide structures of a black smoker (Hedrick et al., 1992). However, the application of molecular-biological methods revealed a quite different picture. Although it could be shown that the diversity of Archaea was

†Present address: Technical University Hamburg-Harburg, Technical Microbiology (AB 2-09), Denickestrasse 15, D-21071 Hamburg. unexpectedly high in terrestrial and marine hydrothermal systems (Barns et al., 1994, 1996; Dando et al., 1998; Takai \& Sako, 1999), it seemed to be the Bacteria that dominated the microbial communities in most of these environments (Reysenbach et al., 1994; Harmsen et al., 1997a; Hugenholtz et al., 1998; Takai \& Sako, 1999). However, in none of these studies was the ratio of the two domains related to the in situ temperature nor was it investigated how this ratio changes along a thermal gradient. This is surprising, since temperature is the most obvious parameter that could determine the relative abundance of Bacteria and Archaea in hydrothermal habitats. In addition, most of these studies have used molecular techniques that are not a priori quantitative.

In the present study we have studied the relative abundance of two domains of life, Archaea and Bacteria 
(Woese et al., 1990), along a thermal gradient at a shallow-water hydrothermal vent. We used slot-blot hybridization of rRNA directly extracted from the sediments to quantify the relative abundance of Archaea and Bacteria with domain-specific probes. This technique has been successfully applied in a variety of environments to estimate the relative abundance of specific groups of micro-organsims (Stahl et al., 1988; Raskin et al., 1994; MacGregor et al., 1997; Massana et al., 1998; Sahm \& Berninger, 1998; Sahm et al., 1999; Vetriani et al., 1999). Concurrently with the sampling, the in situ temperature of the respective samples was determined.

\section{METHODS}

Study site. The study site was a solitary gaseous hydrothermal vent located in $8 \mathrm{~m}$ water in Palaeochori Bay $\left(24^{\circ} 31 \cdot 220^{\prime} \mathrm{E}\right.$; $\left.36^{\circ} 40 \cdot 391^{\prime} \mathrm{N}\right)$, a sandy bay in the south-eastern part of the island Milos in the Aegean Sea (Greece). For a more detailed site description see Sievert et al. (1999).

Sampling and temperature measurements. Sampling was carried out along a transect from the centre of the almost circular vent to the surrounding area. Sediment cores were taken by scuba-divers at specified distances from the vent centre in June 1997. Vertical profiles of temperature were determined in situ up to $12 \mathrm{~cm}$ sediment depth in $1 \mathrm{~cm}$ increments along the same transect, as described by Sievert et al. (1999).

Slicing of sediment cores. Sediment cores were immediately subsampled by extruding the sediment from the polycarbonate tubes and slicing each core. The following depth intervals were sampled: $0-2,2-7,7-12,12-17,17-27,27-37,37-57$, 57-77, 77-97 and 97-117 $\mathrm{mm}$.

RNA extraction. Subsamples $\left(5 \mathrm{~cm}^{3}\right)$ from sliced sediment cores were immediately deep-frozen in liquid nitrogen. For long-term storage, the samples were kept at $-80^{\circ} \mathrm{C}$. RNA was isolated directly from the sediments by bead-beating, phenol extraction and ethanol precipitation, based on methods described elsewhere (MacGregor et al., 1997; Sahm \& Berninger, 1998; Sahm et al., 1999). The extracted RNA was stored at $-80{ }^{\circ} \mathrm{C}$ until further analysis. The quality of the RNA was checked by polyacrylamide gel electrophoresis.

Oligonucleotides. These were purchased from Biometra. The probes used were S-*-Univ-1392-a-A-15 (Stahl et al., 1988), which targets most known forms of life, S-D-Bact-0338-a-A18 (Amann et al., 1990), which is specific for Bacteria and S-DArch-0915-a-A-20 (Stahl \& Amann, 1991), targeting Archaea.

Quantification of domains in environmental samples. For quantitative rRNA hybridization experiments, RNA extracts from natural samples and from suitable reference organisms (Escherichia coli and Methanobacterium bryantii) were loaded onto nylon membranes (Magna Charge; Micron Separations) using a slot-blotting apparatus (Minifold II; Schleicher and Schüll) and probed with radioactively labelled oligonucleotides as described by Stahl et al. (1988). Because the amount of extractable RNA from environmental samples was in some cases very low, i.e. below the detection limit of the gel electrophoresis, we could not blot equal amounts of RNA. When possible, approximately $50 \mathrm{ng}$ RNA was blotted in triplicate. However, in some cases triplicate blotting was not possible due to the low amount of RNA.
After blotting, the membranes were baked at $80^{\circ} \mathrm{C}$ for $1 \mathrm{~h}$. Membranes were further prehybridized at $40^{\circ} \mathrm{C}$ for $1 \mathrm{~h}$ with $10 \mathrm{ml}$ hybridization buffer $\left(0.9 \mathrm{M} \mathrm{NaCl}, 50 \mathrm{mM} \mathrm{NaPO}_{4}, \mathrm{pH}\right.$ 7.2, $5 \mathrm{mM}$ EDTA, pH 7.2, $10 \times$ Denhardt's solution, $0.5 \mathrm{mg}$ polyadenosine $\mathrm{ml}^{-1}, 0.5 \% \mathrm{SDS}$ ), followed by the addition of the $16 \mathrm{~S}$ rRNA oligonucleotide probes (see below) end-labelled with ${ }^{32} \mathrm{P}$. After overnight hybridization at $40{ }^{\circ} \mathrm{C}$, membranes were washed twice at $40{ }^{\circ} \mathrm{C}$ for $1 \mathrm{~h}$ with washing buffer $(1 \%$ SDS, $1 \times$ SSC). Membranes were then transferred to the same buffer preequilibrated to the high-stringency washing temperature $\left(40^{\circ} \mathrm{C}\right.$ for S-*-Univ-1392-a-A-15, $54{ }^{\circ} \mathrm{C}$ for S-D-Bact0338-a-A-18 and $56^{\circ} \mathrm{C}$ for S-D-Arch-0915-a-A-20), washed twice for $15 \mathrm{~min}$, removed and air-dried.

The dried membranes were exposed to Storage PhosphorImager screens (Molecular Dynamics). Subsequently, the hybridization signal intensity was measured with a PhosphorImager (Molecular Dynamics) and quantified with the software package ImageQuant (Molecular Dynamics) relative to suitable reference RNA. For each probe, an individual set of membranes was prepared to which a reference dilution series of reference RNA and the environmental samples were applied. In addition, one membrane was prepared with the dilution series of all reference RNAs for the universal hybridization. This membrane was used to quantify the reference RNA of M. bryantii according to an E. coli standard (Boehringer Mannheim).

\section{RESULTS}

The profiles of the in situ temperature illustrate that the studied vent system was well suited to study the relative distribution of Archaea and Bacteria along an environmental thermal gradient (Fig. 1). It has been shown before that temperature is an important parameter in determining the bacterial community structure (Sievert et al., 1999) and it was expected that it would also influence the relative distribution of Archaea and

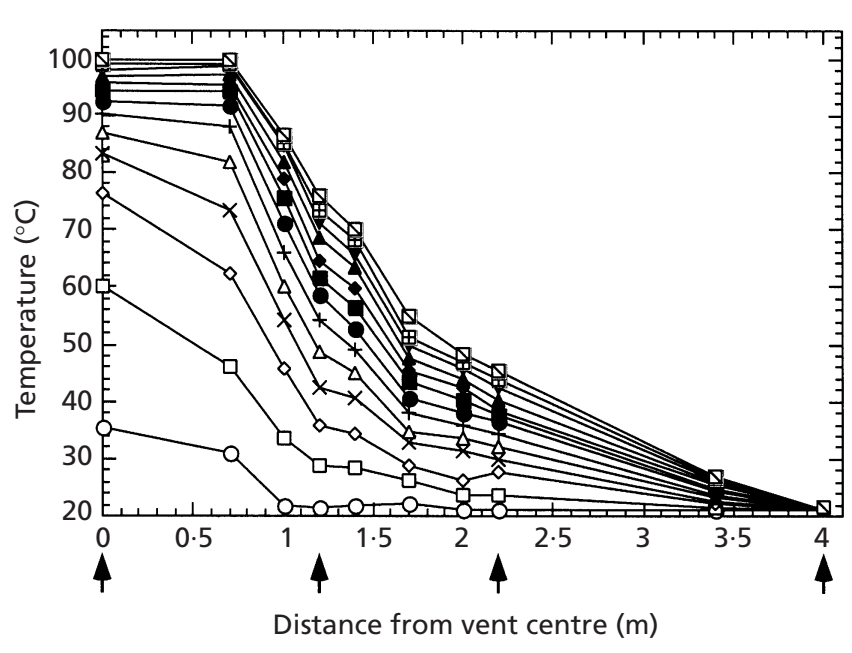

Fig. 1. Profile of in situ temperature along a transect from the centre of the vent to the surrounding area at the following sediment depth: $0 \mathrm{~cm}(\bigcirc), 1 \mathrm{~cm}(\square), 2 \mathrm{~cm}(\diamond), 3 \mathrm{~cm}(\times), 4 \mathrm{~cm}$ $(\triangle), 5 \mathrm{~cm}(+), 6 \mathrm{~cm}(\bullet), 7 \mathrm{~cm}(\boldsymbol{\square}), 8 \mathrm{~cm}(\diamond), 9 \mathrm{~cm}(\Delta), 10 \mathrm{~cm}$ $(\boldsymbol{\nabla}), 11 \mathrm{~cm}(\mathbb{\boxplus})$ and $12 \mathrm{~cm}(\nabla)$. The arrows mark the positions where the sediment cores for the molecular analysis were taken. 


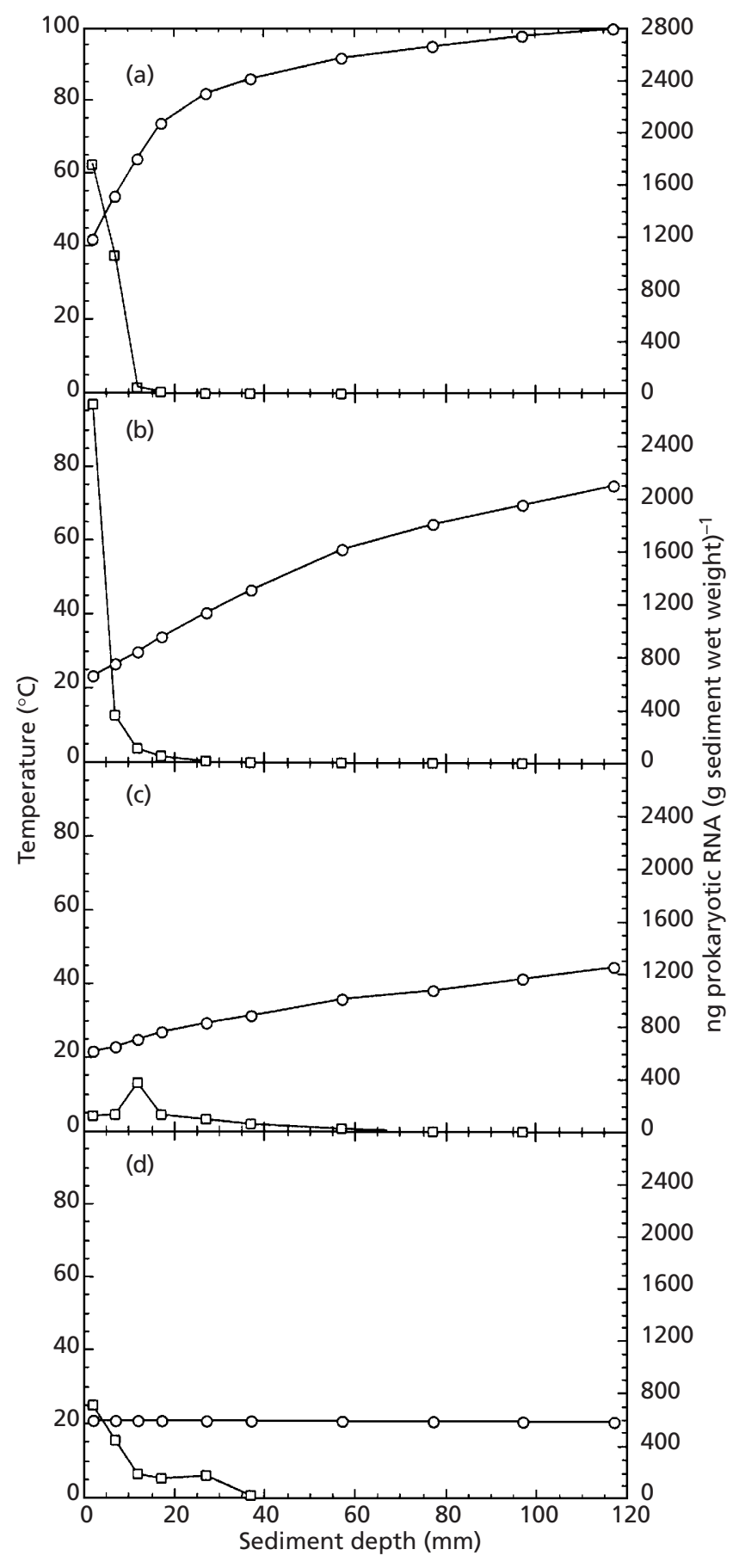

Fig. 2. Profiles of temperature $(O)$ and the concentration of prokaryotic rRNA (sum of bacterial and archaeal rRNA) ( $\square$ ) with sediment depth in the four different cores along the transect: (a) centre, (b) $1.2 \mathrm{~m}$ from vent, (c) $2.2 \mathrm{~m}$ from vent, (d) $4 \mathrm{~m}$ from vent.

Bacteria. Four cores along the transect, which varied in their temperature gradient with sediment depth, were selected to address this question. Apart from temperature, other physico-chemical parameters have previously been determined at this vent.
As a general feature, it was observed that the amount of prokaryotic rRNA (defined as the sum of bacterial and archaeal rRNA) rapidly decreased with sediment depth in all cores, although the decrease seemed to be more pronounced in the zones with the steepest temperature gradient (Fig. 2). In the deeper sediment layers of the cores generally, only very low amounts of rRNA were detected $\left.[<1 \mathrm{ng} \text { (g sediment wet weight })^{-1}\right]$ and a quantification of the two domains was not attempted in these cases. Interestingly, the upper sediment layers of the inner two cores contained a higher amount of prokaryotic rRNA than the outer two cores. The lowest concentrations of prokaryotic rRNA were found $2 \cdot 2 \mathrm{~m}$ from the vent. Bacteria constituted the most important component of the prokaryotic community in all regions and depths, making up at least $78 \%$ (mean $95 \%$ ) of the prokaryotic rRNA (data not shown). Archaea constituted only a small fraction of the prokaryotic community (Table 1). However, there was a trend of an increasing archaeal contribution to prokaryotic rRNA with increasing temperature at the centre of the vent and in the core from $1.2 \mathrm{~m}$ from the centre (Table $1 \mathrm{a}$ and $\mathrm{b}$ ). The increase was from $0.7 \%$ at the surface to $11.9 \%$ at $27 \mathrm{~mm}$ sediment depth at the centre (concurrently, the temperature increased from 42 to $82^{\circ} \mathrm{C}$ ), and from $1 \cdot 1 \%$ at the surface to $22.2 \%$ at $27 \mathrm{~mm}$ sediment depth $1.2 \mathrm{~m}$ from the centre (here the temperature increased from 23.5 to $40.5^{\circ} \mathrm{C}$ ). Such a trend was not apparent in the cores $2 \cdot 2 \mathrm{~m}$ and $4 \mathrm{~m}$ from the vent (Table $1 \mathrm{c}$ and $\mathrm{d}$ ).

\section{DISCUSSION \\ Methodologial considerations}

We have quantified the relative abundance of Archaea and Bacteria at a shallow-water hydrothermal vent by using the hybridization of environmental rRNA with domain-specific oligonucleotides targeting the $16 \mathrm{~S}$ rRNA. Although this method, like any other molecular method, has the advantage that it circumvents selective and potentially ineffective cultivation, it also has limitations. 16S rRNA-targeted probes are widely used in molecular ecology. However, their sequences are based on known sequences in the database and thus new populations that may not contain the target signature sites are not detected (see, for example, Daims et al., 1999). This limitation is more severe in environments where many unknown or new populations are suspected, such as hydrothermal vents (Barns et al., 1994, 1996; Harmsen et al., 1997b; Dando et al., 1998; Hugenholtz et al., 1998; L'Haridon et al., 1998; Takai \& Sako, 1999). The first step in all studies of microbial community analysis by molecular methods is extraction of nucleic acids from the environment. Especially in sediments and soils this poses some challenges, and much remains to be learned about the extraction efficiencies of nucleic acids from this kind of samples. In addition, it is unknown whether there is a difference in the lysing efficiency of archaeal and bacterial cells, for example due to the difference in cellwall composition and structure (MacGregor et al., 
Table 1. Profile of temperature, prokaryotic rRNA, relative abundance of Archaea and the ratio of Bacteria to Archaea in the different cores along the transect

NA, Not analysed; -, not calculated.

\begin{tabular}{|c|c|c|c|c|}
\hline $\begin{array}{l}\text { Depth } \\
(\mathrm{mm})\end{array}$ & $\begin{array}{c}\text { Temp. } \\
\left({ }^{\circ} \mathrm{C}\right)\end{array}$ & $\begin{array}{l}\text { Prokaryotic rRNA } \\
{\left[\text { ng }(\mathrm{g} \text { sediment })^{-1}\right]}\end{array}$ & $\begin{array}{l}\text { Relative abundance } \\
\text { of Archaea } \\
\text { (\% prokaryotic rRNA) }\end{array}$ & $\begin{array}{c}\text { Ratio } \\
\text { Bacteria: Archaea }\end{array}$ \\
\hline \multicolumn{5}{|c|}{ (a) Centre of vent } \\
\hline 2 & 42 & $1749 \cdot 3$ & $0 \cdot 7$ & 139 \\
\hline 7 & 54 & $1051 \cdot 3$ & $1 \cdot 9$ & 51 \\
\hline 12 & 64 & $48 \cdot 0$ & $7 \cdot 3$ & 13 \\
\hline 17 & 74 & $14 \cdot 7$ & $7 \cdot 8$ & 12 \\
\hline 27 & 82 & $2 \cdot 2$ & $11 \cdot 9$ & 7 \\
\hline 37 & 86 & $<1$ & - & - \\
\hline 57 & 92 & $<1$ & - & - \\
\hline 77 & 95 & $<1$ & - & - \\
\hline 97 & 98 & NA & - & - \\
\hline 117 & 100 & NA & - & - \\
\hline \multicolumn{5}{|c|}{ (b) $1.2 \mathrm{~m}$ from vent } \\
\hline 2 & 24 & $2714 \cdot 8$ & $1 \cdot 1$ & 88 \\
\hline 7 & 27 & $354 \cdot 8$ & $3 \cdot 5$ & 28 \\
\hline 12 & 30 & $99 \cdot 4$ & $4 \cdot 8$ & 20 \\
\hline 17 & 34 & $45 \cdot 0$ & $5 \cdot 2$ & 18 \\
\hline 27 & 41 & $17 \cdot 5$ & $22 \cdot 2$ & 3 \\
\hline 37 & 47 & $<2$ & - & - \\
\hline 57 & 58 & $<2$ & - & - \\
\hline 77 & 65 & $<2$ & - & - \\
\hline 97 & 70 & $<2$ & - & - \\
\hline 117 & 75 & $<1$ & - & - \\
\hline \multicolumn{5}{|c|}{ (c) $2.2 \mathrm{~m}$ from vent } \\
\hline 2 & 22 & $111 \cdot 6$ & $3 \cdot 2$ & 30 \\
\hline 7 & 23 & $122 \cdot 8$ & $2 \cdot 7$ & 36 \\
\hline 12 & 25 & $371 \cdot 1$ & $2 \cdot 3$ & 43 \\
\hline 17 & 27 & $123 \cdot 9$ & $2 \cdot 7$ & 36 \\
\hline 27 & 30 & $97 \cdot 8$ & $3 \cdot 4$ & 29 \\
\hline 37 & 32 & $53 \cdot 1$ & $4 \cdot 9$ & 19 \\
\hline 57 & 36 & $29 \cdot 6$ & $8 \cdot 2$ & 11 \\
\hline 77 & 38 & $<2$ & - & - \\
\hline 97 & 42 & $<2$ & - & - \\
\hline 117 & 45 & $<2$ & - & - \\
\hline \multicolumn{5}{|c|}{ (d) $4 \mathrm{~m}$ from vent } \\
\hline 2 & 21 & $703 \cdot 2$ & $2 \cdot 4$ & 41 \\
\hline 7 & 21 & $435 \cdot 4$ & $3 \cdot 0$ & 32 \\
\hline 12 & 21 & $182 \cdot 2$ & $3 \cdot 8$ & 25 \\
\hline 17 & 21 & $153 \cdot 0$ & $2 \cdot 5$ & 38 \\
\hline 27 & 21 & $176 \cdot 7$ & $2 \cdot 4$ & 40 \\
\hline 37 & 21 & $26 \cdot 9$ & $4 \cdot 6$ & 21 \\
\hline 57 & 21 & NA & - & - \\
\hline 77 & 21 & NA & - & - \\
\hline 97 & 21 & NA & - & - \\
\hline 117 & 21 & NA & - & - \\
\hline
\end{tabular}

1997). It is possible that the much lower yield of archaeal rRNA from sediments as compared to pelagic environments is associated with these two biases (Sahm \& Berninger, 1998). Another potential caveat that affects quantification is the unknown relationship between the abundance of rRNA and actual cell numbers, since the content of rRNA per cell varies between species and with growth rate (Devereux et al., 1996; Kemp et al., 1993). Thus, it is possible that certain organisms contribute proportionally more to the total rRNA than 
their cell number would suggest and vice versa. Whether there is a systematic difference in rRNA content per cell between Archaea and Bacteria is not known. The universal probe used in the present study has been shown to overestimate the contribution of Archaea consistently about twofold (Massana et al., 1998). Thus, the data presented here are likely to be conservative with respect to the contribution of bacterial rRNA, and the actual contribution of Archaea may be even lower.

\section{Spatial distribution of prokaryotic rRNA}

If it is assumed that rRNA is an integrated measure of cell number and growth, most of the microbial biomass and growth at the studied hydrothermal vent seems to be present in the first $10-20 \mathrm{~mm}$ of the sediments in all zones. This has also been observed by others, although in these cases the decrease was not as steep (MacGregor et al., 1997; Sahm \& Berninger, 1998; Sahm et al., 1999). However, a similar drastic decrease of rRNA has been observed in sediment samples from a deep-sea vent site in the Guaymas Basin (B. J. MacGregor, personal communication). The analysis of lipids extracted from sediments at a deep-sea hydrothermal vent in the Guaymas Basin also revealed that the active microbial biomass was concentrated in the upper first centimetre and decreased drastically with depth (Guezennec et al., 1996). If a mean rRNA content of $3 \mathrm{fg} \mathrm{cell}^{-1}$ is considered (Sahm \& Berninger, 1998), the calculated cell numbers in the upper layers are in the range of total cell counts that have been determined previously at the same vent (Sievert et al., 1999). In the lower layers there is a discrepancy, which might be related to the fact that a higher percentage of cells was not active and thus contained less rRNA. Interestingly, we found higher concentrations of rRNA in the zones closer to the vent centre. This indicates that the cellular concentration of rRNA was higher at these sites than in the outer zones. This is surprising considering that the highest total cell numbers were found in the outer zone (Sievert et al., 1999). This suggests that the percentage of active cells was higher in the inner zones compared to the outer zones, and it might be related to stimulated microbial activities due to the higher temperatures and certain constituents of the hydrothermal fluid.

\section{Relative abundance of Archaea}

Based on the hybridization analysis Archaea seemed to be of minor importance for the microbial community at this vent site, even in the zones with higher temperatures. This finding was somewhat surprising, but is in line with recent findings by others. As there are Bacteria known that can grow at $80-90{ }^{\circ} \mathrm{C}$, but none that can grow above $97^{\circ} \mathrm{C}$, one may argue that the temperature limit where Archaea will dominate over Bacteria may not have been reached in our investigation. However, in this case one would expect an increase in rRNA at the depth where the temperature seems to be optimal for the Archaea that were isolated from this environment, i.e. at around $90-95{ }^{\circ} \mathrm{C}$ (Jochimsen et al., 1997). Even in this layer, however, the total prokaryotic rRNA concen- tration was very low. Nevertheless, the trend of an increasing contribution of archaeal rRNA with sediment depth in the two inner cores might be seen as an indication for a greater importance of Archaea at higher temperatures. The values reported for the lower layers, i.e. $11.9 \%$ and $22 \%$, are at the upper range of values reported for sediments so far (MacGregor et al., 1997; Sahm \& Berninger, 1998; Sahm et al., 1999; Vetriani et al., 1999), supporting this assumption. However, because of an insufficient RNA recovery, these samples could not be plotted in triplicate. Although this affects the reliability of these data, we are confident that the data are reflecting a real trend, because the variation between triplicate samples was generally low (data not shown) and such a trend was not found in the two outer cores. By using whole-cell hybridization with the same domain-specific probes as used in the present study, it was shown that Archaea constituted up to $77 \%$ of the microbial community in the sulfide structures of a black smoker (calculated from Harmsen et al., 1997a). However, this number was found in the supposedly coldest, outer part of the structure, whereas the lowest percentage of Archaea (1.3 and 1.4\%) was found in the presumably hottest, inner part (data in Harmsen et al., 1997a). Because the absolute yield of archaeal rRNA was quite low in the present study, the actual numbers of archaeal cells are also expected to be small. This suggests that the hyperthermophilic Archaea were occupying only a narrow niche. In future studies, it should be worthwhile to investigate the ecological role of these Archaea in more detail, e.g. to reveal the causes of their high diversity (Dando et al., 1998), despite their apparently low numbers. It would have been interesting to see whether the proportion of Archaea would have continued to increase at even higher temperatures. However, the amount of rRNA that we could extract from these layers was too low to make reasonable quantifications. This problem has been noted before by Hugenholtz et al. (1998), who used the amplification of $16 \mathrm{~S}$ rDNA by PCR because the amount of rRNA was too low to evaluate the relative abundance of Archaea and Bacteria directly. However, the ratio of Bacteria to Archaea they found for three different hot springs (80,75 and 1 , respectively) are comparable to ours and also suggest that the dominance of Archaea in high-temperature environments is the exception rather than the rule. In line with this, Guezennec et al. (1996) also found that Archaea contributed insignificantly to the total microbial biomass at a deep-sea hydrothermal vent in the Guaymas Basin, even in sediments with high in situ temperatures, and by using domain specific rRNA probes H. W. Jannasch and C. O. Wirsen (unpublished, cited in Jannasch, 1995) found a circa 10:1 ratio of Bacteria to Archaea at various locations at the same site.

Overall, the data presented in this paper indicate that the main microbial processes at this hydrothermal vent are occurring in the upper sediment layers and that Bacteria rather than Archaea principally carry out these processes. Furthermore, the hydrothermal activity seemed to stimulate the microbial activity as indicated 
by the higher prokaryotic rRNA concentrations in the regions more strongly affected by the hydrothermalism. However, more studies are required to investigate the ecological roles of Archaea and Bacteria in hightemperature environments in more detail and to unravel the forces that govern their relative abundances.

\section{ACKNOWLEDGEMENTS}

We thank Guido Lützenkirchen and Stefan Forster for scubadiving and help with the field work, Katrin Ravenschlag for help with the molecular analysis, and Barbara MacGregor for the permission to cite unpublished data. Special thanks go to the participants of the EU-funded project Hydrothermal Fluxes and Biological Production in the Aegean for a variety of types of support and help. We also acknowledge the Greek authorities for permission to undertake scuba-diving and fieldwork, and two anonymous referees for their valuable comments.

This work was funded by the EU under MAST CT-95-0021 and the Max-Planck Society, Munich (Germany).

\section{REFERENCES}

Amann, R. I., Binder, B. J., Olson, R. J., Chisholm, S. W., Devereux, R. \& Stahl, D. A. (1990). Combination of $16 \mathrm{~S}$ rRNA-targeted oligonucleotide probes with flow cytometry for analyzing mixed microbial populations. Appl Environ Microbiol 56, 1919-1925.

Barns, S. M., Fundyga, R. E., Jeffries, M. W. \& Pace, N. R. (1994). Remarkable archaeal diversity detected in a Yellowstone $\mathrm{Na}$ tional Park hot spring environment. Proc Natl Acad Sci USA 91, 1609-1613.

Barns, S. R., Delwiche, C. F., Palmer, J. D. \& Pace, N. R. (1996). Perspectives on archaeal diversity, thermophily and monophyly from environmental rRNA sequences. Proc Natl Acad Sci USA 93, 9188-9193.

Baross, J. A. \& Deming, J. W. (1995). Growth at high temperatures: isolation and taxonomy, physiology, and ecology. In The Microbiology of Deep-Sea Hydrothermal Vents, pp. 169-217. Edited by D. M. Karl. Boca Raton, FL: CRC Press.

Daims, H., Brühl, A., Amann, R., Schleifer, K.-H. \& Wagner, M. (1999). The domain-specific probe EUB338 is insufficient for the detection of all Bacteria: development and evaluation of a more comprehensive probe set. Syst Appl Microbiol 22, 434-444.

Dando, P. R., Thomm, M., Arab, H. \& 7 other authors (1998). Microbiology of shallow hydrothermal sites off Palaeochori Bay, Milos (Hellenic Volcanic Arc). Cah Biol Mar 39, 369-372.

Devereux, R., Hines, M. E. \& Stahl, D. A. (1996). S-cycling: characterization of natural communities of sulfate-reducing bacteria by $16 \mathrm{~S}$ rRNA sequence comparisons. Microb Ecol 32, 283-292.

Guezennec, J., Dussauze, J., Bian, M., Rocchiccioli, F., Ringelberg, D., Hedrick, D. B. \& White, D. C. (1996). Bacterial community structure in sediments from Guyamas basin, Gulf of California, as determined by analysis of phospholipid ester-linked fatty acids. $J$ Mar Biotechnol 4, 165-175.

Harmsen, H. J. M., Prieur, D. \& Jeanthon, C. (1997a). Distribution of microorganisms in deep-sea hydrothermal vent chimneys investigated by whole-cell hybridization and enrichment culture of thermophilic subpopulations. Appl Environ Microbiol 63, 2876-2883.

Harmsen, H. J. M., Prieur, D. \& Jeanthon, C. (1997b). Groupspecific $16 \mathrm{~S}$ rRNA-targeted oligonucleotide probes to identify thermophilic bacteria in marine hydrothermal vents. Appl Environ Microbiol 63, 4061-4068.

Hedrick, D. B., Pledger, R. D., White, D. C. \& Baross, J. A. (1992). In situ microbial ecology of hydrothermal vent sediments. FEMS Microbiol Ecol 101, 1-10.

Hugenholtz, P., Pitulle, C., Hershberger, K. L. \& Pace, N. R. (1998). Novel division level bacteria diversity in a Yellowstone hot spring. J Bacteriol 180, 366-376.

Jannasch, H. W. (1995). Microbial interactions with hydrothermal fluids. Geophys Monogr 91, 273-296.

Jochimsen, B., Peinemann-Simon, S., Völker, H., Stüben, D., Botz, R., Stoffers, P., Dando, P. R. \& Thomm, M. (1997). Stetteria hydrogenophila, gen. nov. and sp. nov., a novel mixotrophic sulfur-dependent crenarcheote isolated from Milos, Greece. Extremophiles 1, 67-73.

Kemp, P. F., Lee, S. \& LaRoche, J. (1993). Estimating the growth rate of slowly growing marine bacteria from RNA content. Appl Environ Microbiol 59, 2594-2601.

L'Haridon, S., Cilia, V., Messner, P., Raguénès, G., Gambacorta, A., Sleytr, U. B., Prieur, D. \& Jeanthon, C. (1998). Desulfurobacterium thermolithotrophum gen. nov., sp. nov., a novel autotrophic, sulfur-reducing bacterium isolated from a deep-sea hydrothermal vent. Int J Syst Bacteriol 48, 701-711.

MacGregor, B. J., Moser, D. P., Alm, E. W., Nealson, K. H. \& Stahl, D. A. (1997). Crenarcheaota in Lake Michigan sediment. Appl Environ Microbiol 63, 1178-1181.

Massana, R., Taylor, L. T., Murray, A. E., Wu, K. Y., Jeffrey, W. H. \& DeLong, E. F. (1998). Vertical distribution and temporal variation of marine planktonic archaea in the Gerlache Strait, Antarctica, during early spring. Limnol Oceanogr 43, 607-617.

Raskin, L., Poulsen, L. K., Noguera, D. R., Rittmann, B. E. \& Stahl, D. A. (1994). Quantification of methanogenic groups in anaerobic biological reactors by oligonucleotide probe hybridization. Appl Environ Microbiol 60, 1241-1248.

Reysenbach, A.-L., Wickham, G. S. \& Pace, N. R. (1994). Phylogenetic analysis of the hyperthermophilic pink filament community in Octopus spring, Yellowstone National Park. Appl Environ Microbiol 60, 2113-2119.

Sahm, K. \& Berninger, U. (1998). Abundance, vertical distribution, and community structure of benthic prokaryotes from permanently cold marine sediments (Svalbard, Arctic Ocean). Mar Ecol Prog Ser 165, 71-80.

Sahm, K., MacGregor, B. J., Jørgensen, B. B. \& Stahl, D. A. (1999). Sulphate reduction and vertical distribution of sulphate-reducing bacteria quantified by rRNA slot-blot hybridization in a coastal marine sediment. Environ Microbiol 1, 65-74.

Sievert, S. M., Brinkhoff, T., Muyzer, G., Ziebis, W. \& Kuever, J. (1999). Spatial heterogeneity of bacterial populations along an environmental gradient at a shallow submarine hydrothermal vent near Milos Island (Greece). Appl Environ Microbiol 65, 3834-3842.

Stahl, D. A. \& Amann, R. I. (1991). Development and application of nucleic acid probes in bacterial systematics. In Nucleic Acid Techniques in Bacterial Systematics, pp. 205-248. Edited by E. Stackebrandt \& M. Goodfellow. Chichester: Wiley.

Stahl, D. A., Fleshner, B., Mansfield, H. R. \& Montgomery, L. (1988). Use of phylogenetically based hybridization probes for studies of ruminal microbial ecology. Appl Environ Microbiol 54, 1079-1084.

Stetter, K. O., Fiala, G., Huber, G., Huber, R. \& Segerer, A. (1990). Hyperthermophilic microorganisms. FEMS Microbiol Rev 75, $117-124$. 
Takai, K. \& Sako, Y. (1999). A molecular view of archaeal diversity in marine and terrestrial hot water environments. FEMS Microbiol 28, 177-188.

Vetriani, C., Jannasch, H. W., MacGregor, B. J., Stahl, D. A. \& Reysenbach, A.-L. (1999). Population structure and phylogenetic characterization of marine benthic Archaea in deep-sea sediments. Appl Environ Microbiol 65, 4375-4384.
Woese, C. R., Kandler, O. \& Wheelis, M. L. (1990). Towards a natural system of organisms: proposal for the domains Archaea, Bacteria, and Eucarya. Proc Natl Acad Sci USA 87, 4576-4579.

Received 29 November 1999; revised 17 February 2000; accepted 16 March 2000. 